\title{
Dos novos tempos Cofen à força da mudança: uma nova história nos Conselhos de Enfermagem
}

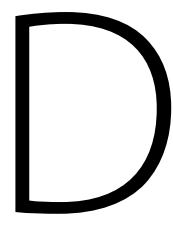

esde 23 de outubro de 2007, o Cofen passa por profundas transformações, buscando a normalidade política e institucional e o reconhecimento da autarquia pelos profissionais de enfermagem, organizações da categoria e pela sociedade brasileira, além do desafio de transformar o Cofen em uma organização republicana e verdadeiramente democrática.

A gestão iniciada naquele ano estabeleceu como prioridade a reforma organizacional para profissionalizar a gestão do Cofen e implantar as rotinas administrativas compatíveis com uma autarquia pública.

Em fevereiro de 2008, logo após assumirmos a gestão, foi adquirida a sede administrativa

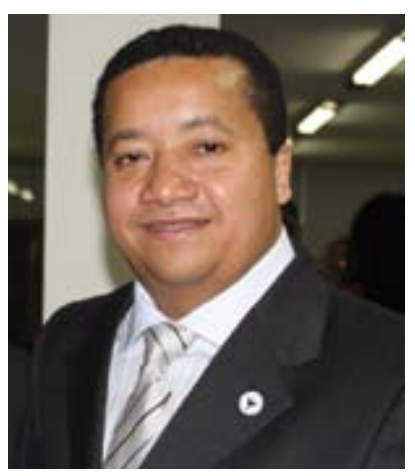
em Brasília-DF, e, com a transferência da sede do Rio de Janeiro, ocorreu a inauguração e o funcionamento efetivo do Cofen em Brasília no dia 12 de julho de 2008. Essa ação atendeu ao que determina a lei de criação dos Conselhos de Enfermagem, antiga reivindicação dos profissionais da categoria, e ao mesmo tempo simbolizou um novo tempo na vida institucional e política do Conselho Federal de Enfermagem.

A reforma administrativa ocorreu com a criação de cargos e funções, a aprovação do organograma e a definição de atribuições para os diversos departamentos e setores recém-criados. Destaca-se a criação da Procuradoria Geral e da Controladoria Geral, estruturas responsáveis por garantir a legalidade dos procedimentos e o cumprimento dos demais princípios constitucionais aplicáveis à gestão pública.

Além dessas, outras prioridades foram definidas, tais como: o investimento na capacitação dos servidores do conselho, a realização de concurso público e a convocação dos servidores aprovados, a reestruturação das licitações com a implantação do pregão presencial e eletrônico e a implantação do sistema de empenho e liquidação de despesas.

Cabe ressaltar, nesse período, a realização do primeiro seminário de planejamento estratégico envolvendo conselheiros, assessores e servidores do conselho, o qual foi essencial para o estabelecimento da missão, visão, valores e definição de metas. Os programas que tiveram origem nesse momento foram desenvolvidos em diversos projetos.

Entre eles, destacamos o Programa de Apoio e Fortalecimento Institucional aos Conselhos Regionais de Enfermagem, que, desde janeiro de 2008, transferiu mais de $\mathrm{R} \$ 30$ milhões em recursos financeiros aos Conselhos Regionais, por meio da aprovação de projetos e da assinatura de convênios para compra, construção, reforma e ampliação de sedes administrativas, aquisição de veículos para implementação das atividades de fiscalização, aquisição de equipamentos de informática e implantação de sistemas de tecnologia da informação, entre outros projetos aprovados. Esse programa vem contribuindo decisivamente para a melhoria da estrutura organizacional, política e administrativa dos Conselhos Regionais, gerando impacto altamente positivo.

Programas e ações inovadoras foram desenvolvidos pelo Cofen e pelos Conselhos de Enfermagem. Destacamos a criação da revista Enfermagem em Foco, lançada em maio de 2010 e que nesse pequeno período se consolidou como um dos mais importantes periódicos científicos da enfermagem brasileira. 
Um processo lento e gradual para resgatar a imagem e a dignidade da autarquia foi iniciado. Logo depois, investimos em ações para resgatar a autoestima do profissional e, finalmente, consolidamos uma nova cultura institucional, tornando a autarquia referência em administração pública entre os conselhos profissionais, cujos resultados positivos são perceptíveis por todos, inclusive junto aos órgãos fiscalizadores do poder público.

Destacamos como símbolo desses novos tempos a aprovação do novo Código Eleitoral em 2009, que consolidou a democracia e os princípios republicanos no âmbito dos Conselhos de Enfermagem, possibilitando a alternância de poder nos cargos de direção, bem como o resgate do papel principal de decisão, pelo voto, nas mãos dos profissionais de enfermagem.

Após 17 anos de afastamento, a enfermagem brasileira retomou o caminho da unidade entre as maiores organizações da categoria no Brasil: o Cofen, a Associação Brasileira de Enfermagem (ABEn) e a Federação Nacional dos Enfermeiros (FNE). O processo dialógico proporcionou unificação de lutas comuns de interesse dos profissionais, como a agenda de lutas em prol da regulamentação da jornada de trabalho em 30 horas semanais.

É importante acrescentar que esta gestão buscou, sobretudo, consolidar-se na esfera pública de decisão e fortalecer os princípios legais e o controle social, a fim de garantir o atendimento dos anseios e as necessidades da sociedade e dos profissionais de enfermagem, dessa forma superando o caráter centralizador, hierárquico e autoritário que dominava a organização.

Estamos chegando ao fim de um ciclo na história do Cofen, com o término do mandato da atual gestão (A Força da Mudança) em 22 de abril de 2012. Novos avanços virão.

Nossa missão tem sido liderar essa transformação em curso, mostrando que é possível cumprir a lei que rege as instituições como o Cofen e estar ao lado das representações democráticas deste país. 